\title{
Ekonomi Syariah Berbasis Entrepreneurship Center
}

\author{
Wadhan \\ Fakultas Ekonomi dan Bisnis Islam IAIN Madura, \\ Email: Wadhanhan@yahoo.co.id
}

\begin{abstract}
Abstrak:
This research aims to examine the effectiveness of the entrepreneurship center laboratory availability at the STAIN Pamekasan Sharia Economics Study Program. This research is a descriptive quantitative research. The purpose of research in general is to describe systematically, factually, and accurately about the facts and nature of the population. Said descriptive because the research aims to make a careful assessment of the phenomenon of perception of students of Islamic Economics Study Program regarding the availability of entrepreneurship centers for all entrepreneurship courses in the semester even 2017/2018 Based on the results of the study that the effectiveness of the entrepreneurship laboratory center must be supported by the time available in the teaching and learning process in the laboratory, the average number of classes taught by lecturers in entrepreneurship courses, and the maximum ability of classes in a day in teaching entrepreneurship and most respondents answered two or just three times the maximum ability of class in a day. In addition, it must also be supported by facilities available in the entrepreneurship center laboratory such as adequate space, computers as required software, air conditioners, considering that in our place the climate is very hot, LCD as an adequate device to support laboratory activities and practical tools others that support the creation of an adequate entrepreneurship center laboratory.

[Penelitian ini bertujuan untuk menguji efektivitas ketersedian laboratorium entrepreneurship center di Program Studi Ekonomi Syariah STAIN Pamekasan. Penelitian ini adalah merupakan penelitian kuantitatif deskriptif. Tujuan penelitian secara umum adalah untuk mendeskripsikan secara sistematis, faktual, dan akurat mengenai fakta dan sifat populasi. Dikatakan diskriptif karena penelitian bertujuan untuk melakukan penilaian secara cermat terhadap fenomena persepsi mahasiswa Prodi Studi Ekonomi Syariah berkenaan dengan tersedianya entrepreneurship center untuk seluruh mata kuliah kewiraushaan pada semester genap tahun 2017/ 2018. Berdasarkan hasil penelitian bahwa efektivitas laboratorium entreprenneurship center harus di dukung oleh waktu yang tersedia dalam proses belajar mengajar di laboratorium, rata-rata jumlah kelas yang diampu oleh dosen dalam mata kuliah kewirausahaan, dan kemampuan maksimal kelas dalam sehari dalam mengajar kewirausahaan dan kebanyakan responden menjawab dua atau tiga kali saja kemampuan maksimal kelas dalam sehari. Selain itu juga harus didukung oleh fasilitas yang tersedia di laboratorium entrepreneurship center seperti ruangan yang memadai, komputer sebagai perangkat lunak yang dibutuhkan, AC mengingat di tempat kita ini iklimnya sangat panas, LCD sebagai perangkat yang memadai untuk menunjang aktivitas laboratorium serta alat-alat praktik yang lain yang mendukung terciptanya laboratorium entrepreneurship center yang memadai.]
\end{abstract}

Kata Kunci: Entrepreneurship Center; Program Studi; Ekonomi Syariah. 


\section{PENDAHULUAN}

Global krisis telah menciptakan multi crisis effect yang membuat banyak perusahaan di Indonesia dengan sangat terpaksa melakukan perampingan organisasi dalam bentuk pemutusan hubungan kerja (PHK) secara sepihak dan dampaknya adalah meningkatnya jumlah angka pengangguran terdidik. Hal ini ditambah lagi dengan kenyataa bahwa setiap tahun lulusan perguruan tinggi yang berjumlah diatas dua jutaan bersaing ketat memasuki dunia kerja. ${ }^{1}$

Indonesia membutuhkan entrepreneurial skill untuk bisa menekan sekecil mungkin tingkat kemiskinan yang tinggi (absolut). Mengandalkan investor asing untuk membuka lapangan kerja tidaklah cukup, menghimbau kepada perusahaan untuk tidak melakukan PHK karyawan juga sulit diwujudkan. Satu-satunya cara atau jalan terbaiknya adalah mengandalkan sektor pendidikan untuk mengubah pola pikir lulusannya dari berorientasi meencari kerja menjadi mencetak lapangan kerja sendiri atau menjadi wirausaha mandiri. Untuk itulah penerapan kurikulum berbasis kewirausahaan (entrepreneurship) begitu penting dan harus segera dilaksanakan. Dunia kerja dengan dunia pendidikan seringnya tidaklah match dengan praktik dan sistem belajar di lembaga pendidikan perguruan tinggi yang kurang mengembangkan jiwa kewirausahaan. Salah satunya yang perlu dilakukan adalah kurikulum dan silabus yang dilengkapi dengan sebuah pedoman kewirausahaan yang lengkap dan yang dapat dipublikasikan, mampu memotivasi, bisa mengubah sikap dan perilaku, yang akhirnya mencetak lulusannya menjadi calon entrepreneur yang cerdas. ${ }^{2}$

Dalam kenyataannya persentase jumlah wirausahawan di Indonesia sangat kecil. Mengapa hal ini bisa terjadi? Karena pengertian dan pemahaman tentang kewirausahaan di kurikulum pendidikan kurang bergema atau hanya sekedar mengetahui dan mengerti saja. Bahkan ada lembaga pendidikan yang belum memperkenalkan kewirausahaan dalam pengembangan kurikulumnya. ${ }^{3}$

Dahulu, prestasi dan pendidikan saja sudah cukup menjadi bekal mencari pekerjaan dan bertahan hidup. Namun dewasa ini prestasi dan pendidikan tidaklah cukup harus disertai sikap dan mental kewirausahaan yang bisa dimanfaatkan oleh para lulusan perguruan tinggi dalam mewujudkan impiannya. Kewirausahaan bukan ilmu ajaib yang mendatangkan uang dalam waktu sekejap. Namun tak bisa disangkal bahwa kewirausahaan memiliki peran yang sangat vital bagi kemajuan setiap insan, daerah, dan bangsa kita. ${ }^{4}$ Beberapa tujuan kewirausahaan untuk mahasiswa/i dan lembaga pendidikan, yaitu: pertama, pendidikan saja tidak cukup menjadi bekal untuk masa depan. Kedua, kewirausahaan bisa diterapkan di semua bidang pekerjaan dan kehidupan. Ketiga, ketika lulusan perguruan tinggi kesulitan mendapatkan pekerjaan atau terkena PHK, kewirausahaan bisa menjadi langkah

\footnotetext{
1 Data Statistik ILO (International Labour Organization) mengatakan bahwa 69\% para muda-mudi di Indonesia menganggur (Sumber: Kompas, 30 September 2008). Hal ini membuat pemerintah Indonesia membutuhkanlangkah dan upaya yang cerdas untuk mengatasi tingkat pengangguran terdidik yang hanya berorientasi mencari kerja bukan menciptakan lapangan pekerjaan.

2 Hendro, Dasar-Dasar Kewirausahaan, Jakarta: t.tp., 2011, 1.

3 Negara maju pada umumnya memiliki wirausahawan yang lebih banyak dibandingkan dengan negara berkembang apalagi negara miskin. Amerika Serikat memiliki 11,5\% dari total penduduknya, Singapura 7,2\%, Malaysia lebih dari 3\%, dan Indonesia dengan segala sumber daya alam yang dimiliki hanya lebih dari $1 \%$. Data Young Biz Indonesia menyebutkan hampir 10\% dari 110 Juta tenaga kerja di Indonesia adalah pengangguran. Setiap tahun lulusan perguruan tinggi dan sederajat berjumlah jutaan dan hampir sebagian besar dari lulusan itu berorientasi mencari kerja. Itupun belum ditambah dengan lulusan tahun sebelumnya yang jumlahnya jutaan dan masih belum mendapatkan pekerjaan.

${ }^{4}$ Kewirausahaan atau entrepreneurship bukan Cuma diartikan sebagai keterampilan bisnis. Lebih penting dari itu. Kewirausahaan adalah sikap, kreatif, inovatif, dan berani mengambil keputusan sehingga dijadikan sikap hidup bahkan karakter bangsa Indonesia (Ciputra, Tokoh Pendidikan Kewirausahaan, Kompas, Selasa, 30 November 2009).
} 
alternatif untuk mencari nafkah dan bertahan hidup. Keempat, agar sukses di dunia kerja, tidak cukup orang hanya pandai bicara, yang dibutuhkan adalah bukti nyata. Oleh karena itu, kewirausahaan adalah ilmu nyata yang bisa mewujudkannya. Kelima, memajukan perekonomian Indonesia dan menjadi lokomotif peningkatan kesejahteraan dan kemakmuran bangsa Indonesia.

Di STAIN Pamekasan (sekarang IAIN Madura) memiliki tiga Jurusan yaitu, Jurusan Tarbiyah, Jurusan Syariah, dan Jurusan Ekonomi dan Bisnis Islam. Pada Jurusan Ekonomi dan Bisnis Islam ini memiliki tiga Program Studi yakni, Program Studi Perbankan Syariah, Program Studi Ekonomi Islam Dan Program Studi Akuntansi Syariah. Jurusan Ekonomi dan Bisnis Islam ini memiliki beberapa Laboratorium diantaranya Laboratorium Bank Mini Syariah (BMS), Laboratorium Galeri Investasi (GI), Laboratorium Akuntansi dan Laboratorium Statistik. Program Studi Ekonomi Syariah dengan Nomor SK Pendirian: Sti.07/PP 00.9/1712/2013. Dan Tanggal SK Pendirian 04 Februari 2013. Bulan dan tahun dimulainya penyelenggaraan Program Studi Ekonomi Syariah 14 Maret 2014 dan Nomor SK Ijin Operasional: 1492 Tahun 2014. Di Program Stusi Ekonomi Syariah mata kuliah entrepreneurship di gelar di semester dua dan praktik kewirausahaan di gelar di semester lima. Sehingga dianggap penting untuk mempunyai laboratorium entrepreneurship center dengan alasan bahwa mahasiswa tidak hanya paham teori-teori tentang kewirausahaan tetapi, lebih dari itu mahasiswa di harapkan memiliki sikap dan mental entrepreneur sehingga lulusannya memiliki kompetensi lulusan yang andal dan cerdas dibidang kewirausahaan.

Dari uraian di atas, penulis ingin menguji efektivitas ketersedian laboratorium entrepreneurship center di Program Studi Ekonomi Syariah STAIN Pamekasan secara terbatas.

\section{METODE PENELITIAN}

Penelitian ini adalah merupakan penelitian kuantitatif deskriptif. Tujuan penelitian secara umum adalah untuk mendeskripsikan secara sistematis, faktual, dan akurat mengenai fakta dan sifat populasi ${ }^{5}$. Dikatakan diskriptif karena penelitian bertujuan untuk melakukan penilaian secara cermat terhadap fenomena persepsi mahasiswa Prodi Studi Ekonomi Syariah berkenaan dengan tersedianya entrepreneurship center untuk seluruh mata kuliah kewiraushaan pada semester genap tahun 2017/ 2018.

Dalam penelitian ini yang akan dimintai pendapat adalah 2204 mahasiswa, dan 32 dosen. Berdasarkan karakteristik populasinya maka teknik pemilihan sampelnya adalah Probability Sampling dengan jenis Proportional Stratified Random Sampling. 6 Untuk mahasiswa stratifikasi berdasarkan angkatan, dosen berdasarkan prodi dan karyawan berdasarkan unit kerja. Sedangkan jumlah sampel yang diteliti berdasarkan penghitungan dengan tabel Krecjie. Dari penghitungan tersebut didapatkan sampel untuk mahasiswa berjumlah 205 orang yang akan distratifikasi berdasarkan prodi dan angkatan, dosen sebanyak 32 orang.

\footnotetext{
5 Murti dan Salamah, Metodologi Penelitian Bisnis, Yogyakarta: Andi, 2005, 52.

6 Ibid., 61-62.
} 
HASIL DAN PEMBAHASAN

Dari hasil penelitian ini, penulis dapat sajikan data-data sebagai berikut:

Tabel 1

Uji Validitas Dosen

\begin{tabular}{llll}
\hline \multicolumn{1}{c}{ Variabel } & \multicolumn{1}{c}{ Korelasi } & Sign & Keterangan \\
\hline X5 & $.525^{* *}$ & .000 & Valid \\
X6 & $.616^{* *}$ & .000 & Valid \\
X7 & $.519^{* *}$ & .000 & Valid \\
X8 & $.484^{* *}$ & .000 & Valid \\
X9 & $.594^{* *}$ & .000 & Valid \\
X10 & $.709^{* *}$ & .000 & Valid \\
X11 & $.675^{* *}$ & .000 & Valid \\
X12 & $.577^{*}$ & .000 & Valid \\
X13 & $.521^{*}$ & .000 & Valid \\
X14 & $.525^{* *}$ & .000 & Valid \\
X15 & $.755^{* *}$ & .000 & Valid \\
X16.a & $.720^{* *}$ & .000 & Valid \\
X16.b & $.756^{* *}$ & .000 & Valid \\
X16.c & $.793^{* *}$ & .000 & Valid \\
X16.d & $.845^{* *}$ & .000 & Valid \\
X16.e & $.797^{* *}$ & .000 & Valid \\
\hline
\end{tabular}

Sumber: Output SPSS, Data Diolah Tahun 2018.

Dari tabel di atas, dapat diketahui bahwa R tabel untuk data dengan jumlah 32 dengan tingkat ketelitian 95\% adalah 0,3494, Nilai korelasi yang lebih besar dari 0,3494 menunjukkan bahwa variabel tersebut valid dan sebaliknya. Atau jika dilihat dari nilai signifikansinya, maka variabel yang memiliki nilai signifikansi dua arah (sig. 2-tailed) atau disebut juga $p$-value di bawah $5 \%$ atau di bawah alfa menunjukkan bahwa variabel dalam penelitian ini sudah valid dan sebaliknya. Hasil uji validitas instrumen untuk dosen menunjukkan bahwa ada semua variabel valid dan akan dilakukan analisis lebih lanjut.

Tabel 2

Uji Validitas Mahasiswa

\begin{tabular}{llll}
\hline Variabel & Korelasi & Sign & Keterangan \\
\hline X5 & $.334^{* *}$ & .000 & Valid \\
X6 & $.411^{* *}$ & .000 & Valid \\
X7 & $.548^{* *}$ & .000 & Valid \\
X8 & $.476^{* *}$ & .000 & Valid \\
X9 & $.442^{* *}$ & .000 & Valid \\
X10 & $.521^{* *}$ & .000 & Valid \\
X11 & $.594^{* *}$ & .000 & Valid \\
X12 & $.577^{* *}$ & .000 & Valid \\
X13 & $.585^{* *}$ & .000 & Valid \\
X14 & $.693^{* *}$ & .000 & Valid \\
X15 & $.569^{* *}$ & .000 & Valid \\
X16.a & $.494^{* *}$ & .000 & Valid \\
X16.b & $.463^{* *}$ & .000 & Valid \\
X16.c & $.585^{* *}$ & .000 & Valid \\
\hline
\end{tabular}


Wadhan

\begin{tabular}{cccc}
\hline X16.d & $.589^{* *}$ & .000 & Valid \\
X16.e & $.549^{* *}$ & .000 & Valid \\
\hline Sumber: Output SPSS, Data Diolah Tahun 2018. &
\end{tabular}

Sumber: Output SPSS, Data Diolah Tahun 2018.

Mahasiswa yang menjadi responden dalam penelitian ini sejumlah 100 orang. R tabel untuk data dengan jumlah 100 dengan tingkat ketelitian 95\% adalah 0,1966, Nilai korelasi yang lebih besar dari 0,1966 menunjukkan bahwa variabel tersebut valid dan sebaliknya. Atau jika dilihat dari nilai signifikansinya, maka variabel yang memiliki nilai signifikansi dua arah (sig. 2-tailed) atau disebut juga $p$-value di bawah $5 \%$ atau di bawah alfa menunjukkan bahwa variabel dalam penelitian ini sudah valid dan sebaliknya.

\section{Uji Realibilitas Instrumen}

Uji reliabilitas berfungsi untuk mengetahui konsistensi hasil sebuah jawaban ditunjukkan pada Lampiran 3 dan dirangkum dalam Tabel 3. Nilai Cronbach's Alpha dianggap tinggi jika nilainya antara 0,6 sampai 0,8 dan sangat tinggi jika di atas 0,8 sedangkan jika kurang dari 0,4 dianggap kurang baik.

Tabel 3

Hasil Uji Reliabilitas Instrumen

\begin{tabular}{llll}
\hline \multicolumn{1}{c}{ Variabel } & \multicolumn{1}{c}{ Cronbach's Alpha } & \multicolumn{1}{c}{$\mathbf{N}$} & Keterangan \\
\hline Mahasiswa & .824 & 100 & Realibel \\
Dosen & .907 & 32 & Reliabel \\
\hline
\end{tabular}

Sumber : Output SPSS, Data diolah, Tahun 2018.

Semua variabel yang diuji apabila dilihat dari Tabel 3 adalah reliabel dengan nilai Cronbach's Alpha lebih dari 0,6, sehingga dapat dikatakan bahwa semua variabel pada penelitian ini reliabel dengan tingkat reliabilitas mahasiswa dan dosen terkategori tinggi terkategori memiliki tingkat reliabilitas sangat tinggi.

Gambar 1

Waktu Praktik Kewirausahaan

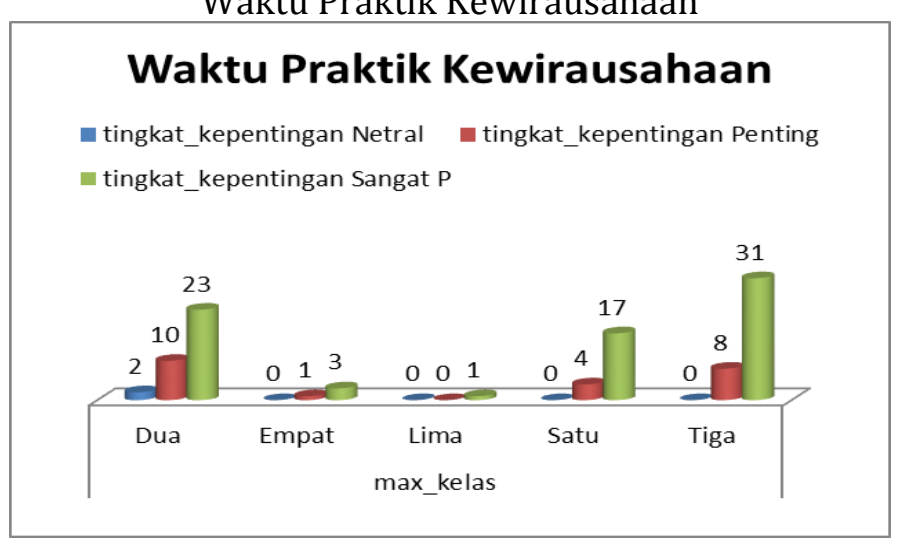

Sumber: Output SPSS, Data Diolah Tahun 2018.

Informasi tentang perkuliahan mata kuliah kewirausahaan bisa terdiri dari waktu perkuliahan kewirausahaan, rata-rata mata kuliah kewirausahaan disajikan dalam seminggu, dan praktik kewirausahaan yang disajikan dalam seminggu. Pada gambar.4.8 menunjukkan bahwa seberapa penting ketersedian laboratorium entrepreneurship center dikaitkan dengan 
waktu perkuliahan kewirausahaan adalah responden yang menjawab netral pada hari senin adalah 0 atau tidak ada, yang menjawab penting pada hari senin adalah sebanyak 6 orang (18\%), dan yang menjawab sangat penting pada hari senin adalah sebanyak 28 orang (82\%), responden yang menjawab netral pada hari selasa adalah 2 orang (33\%), yang menjawab penting pada hari selasa adalah sebanyak 0 , dan yang menjawab sangat penting pada hari selasa adalah sebanyak 4 orang (76\%), responden yang menjawab netral pada hari rabu adalah 0 atau tidak ada, yang menjawab penting pada hari rabu adalah sebanyak 14 orang (25\%), dan yang menjawab sangat penting pada hari rabu adalah sebanyak 41 orang $(75 \%)$, dan responden yang menjawab netral pada hari kamis adalah 0 atau tidak ada, yang menjawab penting pada hari kamis adalah sebanyak 3 orang (60\%), dan yang menjawab sangat penting pada hari kamis adalah sebanyak 2 orang (40\%).

Pada gambar.1 menunjukkan bahwa seberapa penting ketersedian laboratorium entrepreneurship center dikaitkan dengan rata-rata perkuliahan dalam perminggu adalah responden yang menjawab netral terhadap rata-rata perkuliahan kewirausahaan dalam perminggu satu kali adalah sebanyak 2 orang (2\%), responden yang menjawab penting terhadap rata-rata perkuliahan kewirausahaan dalam perminggu satu kali adalah sebanyak 21 orang $(25 \%)$, dan responden yang menjawab sangat penting terhadap rata-rata perkuliahan kewirausahaan dalam perminggu satu kali adalah sebanyak 61 orang (73\%), responden yang menjawab netral terhadap rata-rata perkuliahan kewirausahaan dalam perminggu dua kali adalah 0 atau tidak ada, responden yang menjawab penting terhadap rata-rata perkuliahan kewirausahaan dalam perminggu dua kali adalah sebanyak 2 orang (13\%), dan responden yang menjawab sangat penting terhadap rata-rata perkuliahan kewirausahaan dalam perminggu dua kali adalah sebanyak 13 orang (87\%), sedangkan responden yang menjawab netral terhadap rata-rata perkuliahan kewirausahaan dalam perminggu tiga kali adalah 0 atau tidak ada, responden yang menjawab penting terhadap rata-rata perkuliahan kewirausahaan dalam perminggu tiga kali adalah sebanyak 0 atau tidak ada, dan responden yang menjawab sangat penting terhadap rata-rata perkuliahan kewirausahaan dalam perminggu tiga kali adalah sebanyak 1 orang $(100 \%)$.

Pada gambar.1 menunjukkan bahwa seberapa penting ketersedian laboratorium entrepreneurship center dikaitkan dengan praktik kewirausahaan harus digelar dalam perminggu adalah responden yang menjawab netral terhadap praktik kewirausahaan yang harus di gelar perminggu satu kali adalah sebanyak 0 atau tidak ada, responden yang menjawab penting terhadap praktik kewirausahaan yang harus di gelar perminggu satu kali adalah sebanyak 4 orang (19\%), dan responden yang menjawab sangat penting terhadap praktik kewirausahaan yang harus di gelar perminggu satu kali adalah sebanyak 17 orang (81\%). Responden yang menjawab netral terhadap praktik kewirausahaan yang harus di gelar perminggu dua kali adalah sebanyak 2 orang (6\%), responden yang menjawab penting terhadap praktik kewirausahaan yang harus di gelar perminggu dua kali adalah sebanyak 10 orang (28\%), dan responden yang menjawab sangat penting terhadap praktik kewirausahaan yang harus di gelar perminggu dua kali adalah sebanyak 23 orang (66\%). Responden yang menjawab netral terhadap praktik kewirausahaan yang harus di gelar perminggu tiga kali adalah sebanyak 0 atau tidak ada, responden yang menjawab penting terhadap praktik kewirausahaan yang harus di gelar perminggu tiga kali adalah sebanyak 8 orang (21\%), dan responden yang menjawab sangat penting terhadap praktik kewirausahaan yang harus di gelar perminggu tiga kali adalah sebanyak 31 orang (79\%). Responden yang menjawab netral terhadap praktik kewirausahaan yang harus di gelar perminggu empat kali adalah sebanyak 0 atau tidak ada, responden yang menjawab penting terhadap praktik kewirausahaan yang harus di gelar perminggu empat kali adalah sebanyak 1 orang (25\%), dan responden yang menjawab sangat penting terhadap praktik kewirausahaan yang harus di gelar perminggu 
empat kali adalah sebanyak 3 orang (75\%). Dan Responden yang menjawab netral terhadap praktik kewirausahaan yang harus di gelar perminggu lima kali adalah sebanyak 0 atau tidak ada, responden yang menjawab penting terhadap praktik kewirausahaan yang harus di gelar perminggu lima kali adalah sebanyak 0 atau tidak ada dan responden yang menjawab sangat penting terhadap praktik kewirausahaan yang harus di gelar perminggu lima kali adalah sebanyak 1 orang $(100 \%)$.

Gambar 2

Waktu Perkuliahan

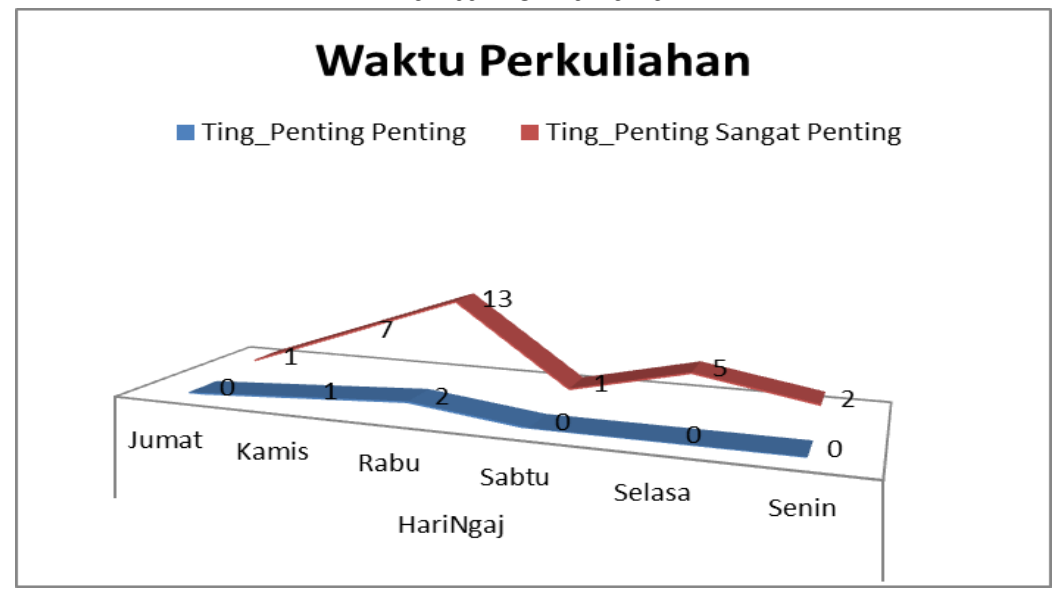

Sumber: Output SPSS, Data Diolah Tahun 2018.

Gambar 3

Rata-rata Kelas yang Diampu

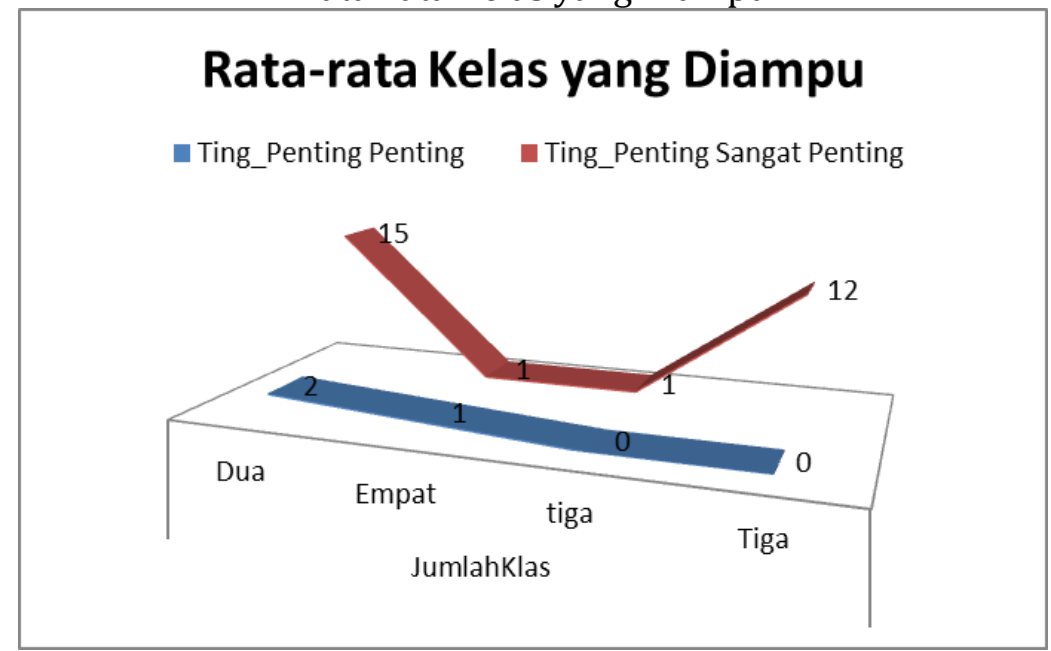

Sumber: Output SPSS, Data Diolah Tahun 2018. 
Gambar 4

Kemampuan Maksimal

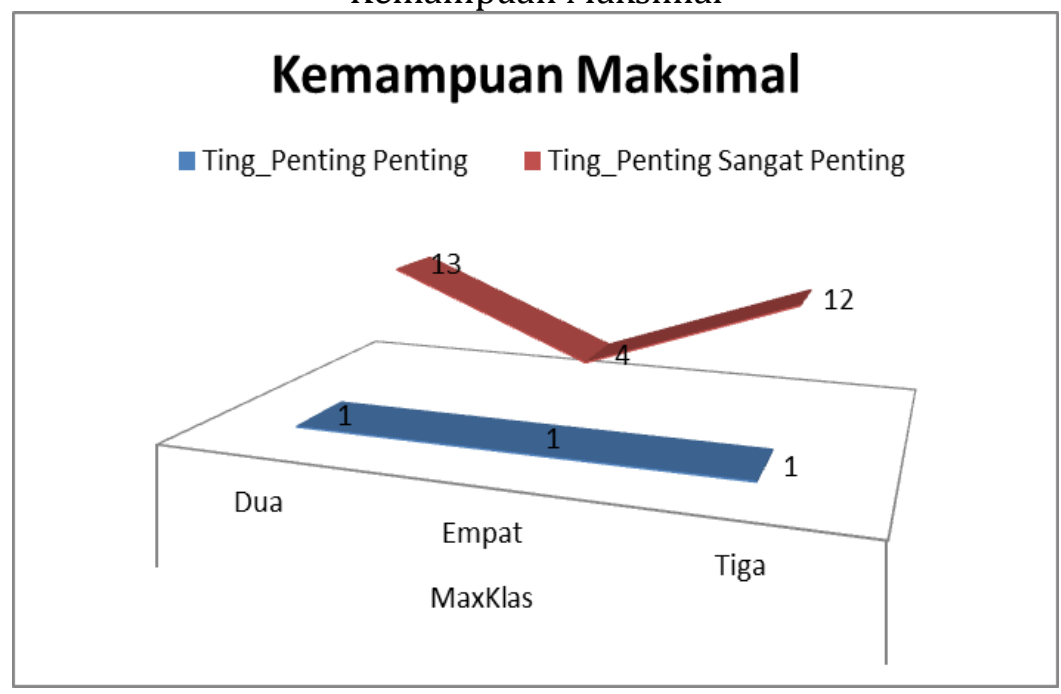

Sumber: Output SPSS, Data Diolah Tahun 2018.

Informasi tentang perkuliahan mata kuliah kewirausahaan bisa terdiri dari waktu perkuliahan atau hari apa saja mengajar mata kuliah kewirausahaan, rata-rata jumlah kelas mata kuliah kewirausahaan disajikan dalam seminggu, dan kemampuan maksimal dalam hal jumlah kelas perhari. Pada gambar.4 menunjukkan bahwa seberapa penting ketersedian laboratorium entrepreneurship center dikaitkan dengan waktu perkuliahan atau hari apa saja mengajar mata kuliah kewirausahaan adalah responden yang menjawab penting pada hari senin adalah 0 atau tidak ada, dan yang menjawab sangat penting pada hari senin adalah sebanyak 2 orang $(100 \%)$, responden yang menjawab penting pada hari selasa adalah sebanyak 0 atau tidak ada, dan yang menjawab sangat penting pada hari selasa adalah sebanyak 5 orang $(100 \%)$, responden yang menjawab penting pada hari rabu adalah sebanyak 2 orang (13\%), dan yang menjawab sangat penting pada hari rabu adalah sebanyak 13 orang (87\%), responden yang menjawab yang menjawab penting pada hari kamis adalah sebanyak 1 orang $(12 \%)$, responden yang menjawab sangat penting pada hari kamis adalah sebanyak 7 orang (88\%). dan responden yang menjawab penting pada hari jumat adalah sebanyak 0 atau tidak ada dan yang menjawab sangat penting pada hari jumaat adalah sebanyak 1orang (100\%). dan responden yang menjawab yang menjawab penting pada hari sabtu adalah 0 atau tidak ada dan yang menjawab sangat penting pada hari sabtu adalah sebanyak 1 orang $(100 \%)$.

Pada gambar 4 menunjukkan bahwa seberapa penting ketersedian laboratorium entrepreneurship center dikaitkan dengan rata-rata jumlah kelas yang diampu dalam matakuliah kewirausahaan, responden yang menjawab penting terhadap rata-rata jumlah kelas yang diampu dalam matakuliah kewirausahaan dua kelas perminggu adalah sebanyak 2 orang (12\%), dan responden yang menjawab sangat penting terhadap rata-rata perkuliahan kewirausahaan dua kelas perminggu adalah sebanyak 15 orang (88\%), responden yang menjawab penting terhadap rata-rata jumlah kelas yang diampu dalam matakuliah kewirausahaan tiga kelas perminggu adalah sebanyak 0 atau tidak ada, dan responden yang menjawab sangat penting terhadap rata-rata perkuliahan kewirausahaan tiga kelas perminggu adalah sebanyak 12 orang $(100 \%)$, responden yang menjawab penting terhadap rata-rata jumlah kelas yang diampu dalam matakuliah kewirausahaan empat kelas perminggu adalah sebanyak 1 orang (50\%), dan responden yang menjawab sangat penting 
terhadap rata-rata perkuliahan kewirausahaan empat kelas perminggu adalah sebanyak 1 orang $(50 \%)$, responden yang menjawab penting terhadap rata-rata jumlah kelas yang diampu dalam matakuliah kewirausahaan lima kelas perminggu adalah sebanyak 0 atau tidak ada, dan responden yang menjawab sangat penting terhadap rata-rata perkuliahan kewirausahaan lima kelas perminggu adalah sebanyak 1 orang (100\%).

Pada gambar 4 menunjukkan bahwa seberapa penting ketersedian laboratorium entrepreneurship center dikaitkan dengan kemampuan maksimal dalam jumlah hal kelas sehari adalah responden yang menjawab penting terhadap kemampuan maksimal dalam jumlah hal kelas sehari dua kali adalah sebanyak 1 orang (7\%), dan responden yang menjawab sangat penting terhadap kemampuan maksimal dalam jumlah hal kelas dua kali adalah sebanyak 15 orang (93\%), responden yang menjawab penting terhadap kemampuan maksimal dalam jumlah hal kelas sehari tiga kali adalah sebanyak 1 orang (8\%), dan responden yang menjawab sangat penting terhadap kemampuan maksimal dalam jumlah hal kelas tiga kali adalah sebanyak 12 orang (92\%), sedangkan responden yang menjawab penting terhadap kemampuan maksimal dalam jumlah hal kelas sehari empat kali adalah sebanyak 1 orang (20\%), dan responden yang menjawab sangat penting terhadap kemampuan maksimal dalam jumlah hal kelas empat kali adalah sebanyak 4 orang (80\%).

Pada Program Studi Ekonomi Syariah mata kuliah entrepreneurship di gelar di semester dua dan praktik kewirausahaan di gelar di semester lima. Sehingga dianggap penting untuk mempunyai laboratorium entrepreneurship center dengan alasan bahwa mahasiswa tidak hanya paham teori-teori tentang kewirausahaan tetapi, lebih dari itu mahasiswa di harapkan memiliki sikap dan mental entrepreneur sehingga lulusannya memiliki kompetensi lulusan yang andal dan cerdas dibidang kewirausahaan. Efektivitas laboratorium entreprenneurship center juga harus di dukung oleh ini dapat dilihat pada gambar berikut:

Gambar 5

Waktu Perkuliahan

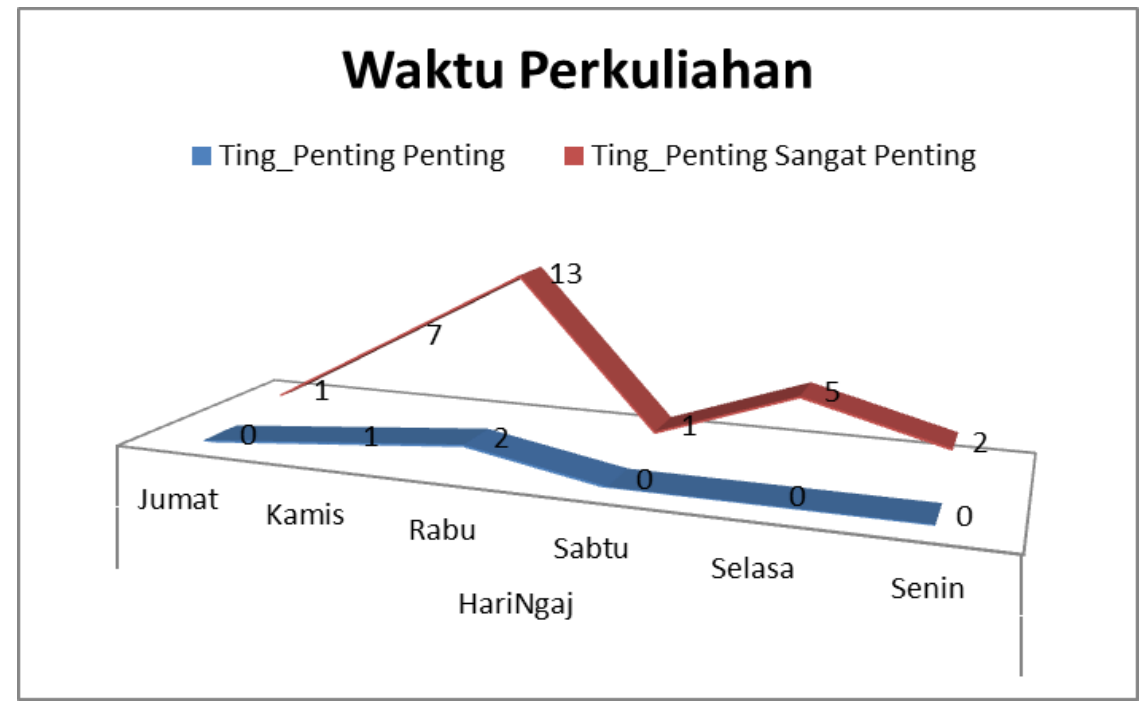

Sumber: Output SPSS, Data Diolah Tahun 2018. 
Gambar 6

Rata-rata Kelas yang Diampu

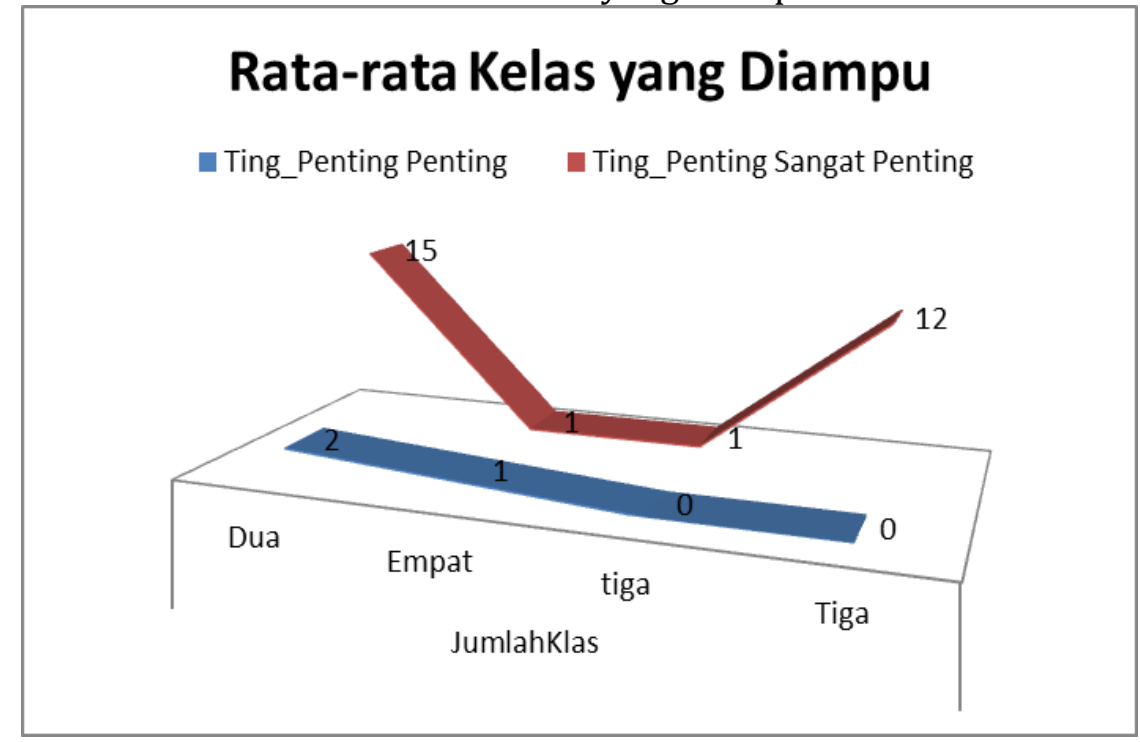

Sumber: Output SPSS, Data Diolah Tahun 2018.

Gambar 7

Kemampuan Maksimal

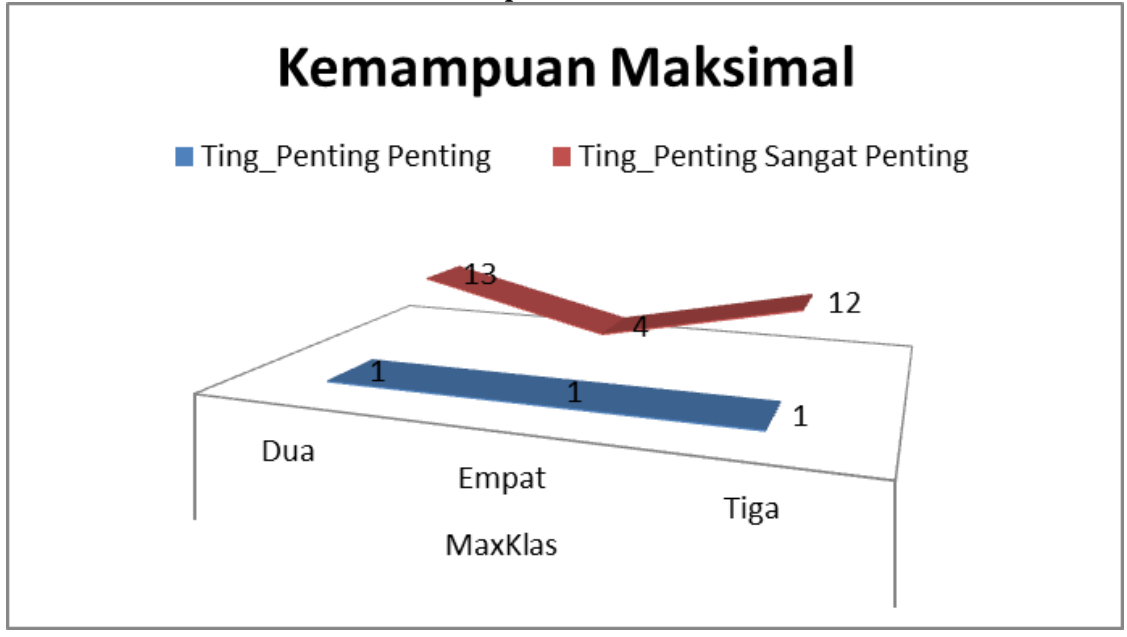

Sumber: Output SPSS, Data Diolah Tahun 2018.

Informasi tentang perkuliahan mata kuliah kewirausahaan bisa terdiri dari waktu perkuliahan atau hari apa saja mengajar mata kuliah kewirausahaan, rata-rata jumlah kelas mata kuliah kewirausahaan disajikan dalam seminggu, dan kemampuan maksimal dalam hal jumlah kelas perhari. Pada gambar 5 menunjukkan bahwa seberapa penting ketersedian laboratorium entrepreneurship center dikaitkan dengan waktu perkuliahan atau hari apa saja mengajar mata kuliah kewirausahaan adalah responden yang menjawab penting pada hari senin adalah 0 atau tidak ada, dan yang menjawab sangat penting pada hari senin adalah sebanyak 2 orang $(100 \%)$, responden yang menjawab penting pada hari selasa adalah sebanyak 0 atau tidak ada, dan yang menjawab sangat penting pada hari selasa adalah sebanyak 5 orang $(100 \%)$, responden yang menjawab penting pada hari rabu adalah sebanyak 2 orang (13\%), dan yang menjawab sangat penting pada hari rabu adalah sebanyak 
13 orang (87\%), responden yang menjawab yang menjawab penting pada hari kamis adalah sebanyak 1 orang $(12 \%)$, responden yang menjawab sangat penting pada hari kamis adalah sebanyak 7 orang (88\%). dan responden yang menjawab penting pada hari jumat adalah sebanyak 0 atau tidak ada dan yang menjawab sangat penting pada hari jumaat adalah sebanyak 1orang (100\%). dan responden yang menjawab yang menjawab penting pada hari sabtu adalah 0 atau tidak ada dan yang menjawab sangat penting pada hari sabtu adalah sebanyak 1 orang (100\%), artinya pada hari-hari tertentu dosen mengajar mata kuliah kewirausahaan itu sangat penting karena beberapa alasan misalnya hari selasa, rabu, dan kamis dianggap sangat efektif dalam menyampaikan materi perkuliahan.

Pada gambar 5 menunjukkan bahwa seberapa penting ketersedian laboratorium entrepreneurship center dikaitkan dengan rata-rata jumlah kelas yang diampu dalam matakuliah kewirausahaan, responden yang menjawab penting terhadap rata-rata jumlah kelas yang diampu dalam matakuliah kewirausahaan dua kelas perminggu adalah sebanyak 2 orang (12\%), dan responden yang menjawab sangat penting terhadap rata-rata perkuliahan kewirausahaan dua kelas perminggu adalah sebanyak 15 orang (88\%), responden yang menjawab penting terhadap rata-rata jumlah kelas yang diampu dalam matakuliah kewirausahaan tiga kelas perminggu adalah sebanyak 0 atau tidak ada, dan responden yang menjawab sangat penting terhadap rata-rata perkuliahan kewirausahaan tiga kelas perminggu adalah sebanyak 12 orang $(100 \%)$, responden yang menjawab penting terhadap rata-rata jumlah kelas yang diampu dalam matakuliah kewirausahaan empat kelas perminggu adalah sebanyak 1 orang (50\%), dan responden yang menjawab sangat penting terhadap rata-rata perkuliahan kewirausahaan empat kelas perminggu adalah sebanyak 1 orang $(50 \%)$, responden yang menjawab penting terhadap rata-rata jumlah kelas yang diampu dalam matakuliah kewirausahaan lima kelas perminggu adalah sebanyak 0 atau tidak ada, dan responden yang menjawab sangat penting terhadap rata-rata perkuliahan kewirausahaan lima kelas perminggu adalah sebanyak 1 orang $(100 \%)$.

Pada gambar 6 menunjukkan bahwa seberapa penting ketersedian laboratorium entrepreneurship center dikaitkan dengan kemampuan maksimal dalam jumlah hal kelas sehari adalah responden yang menjawab penting terhadap kemampuan maksimal dalam jumlah hal kelas sehari dua kali adalah sebanyak 1 orang (7\%), dan responden yang menjawab sangat penting terhadap kemampuan maksimal dalam jumlah hal kelas dua kali adalah sebanyak 15 orang (93\%), responden yang menjawab penting terhadap kemampuan maksimal dalam jumlah hal kelas sehari tiga kali adalah sebanyak 1 orang (8\%), dan responden yang menjawab sangat penting terhadap kemampuan maksimal dalam jumlah hal kelas tiga kali adalah sebanyak 12 orang (92\%), sedangkan responden yang menjawab penting terhadap kemampuan maksimal dalam jumlah hal kelas sehari empat kali adalah sebanyak 1 orang (20\%), dan responden yang menjawab sangat penting terhadap kemampuan maksimal dalam jumlah hal kelas empat kali adalah sebanyak 4 orang $(80 \%)$. Selain penjelasan tiga gambar diatas tersebut ini penting juga didukung oleh fasilitas yang ada di laboratorium entrepreneurship center sehingga ketersedian laboratorium entrepreneurship center menjadi bermanfaat bagi seluruh civitas akademik STAIN Pamekasan. 
Gambar 8

Ruang Laboratorium

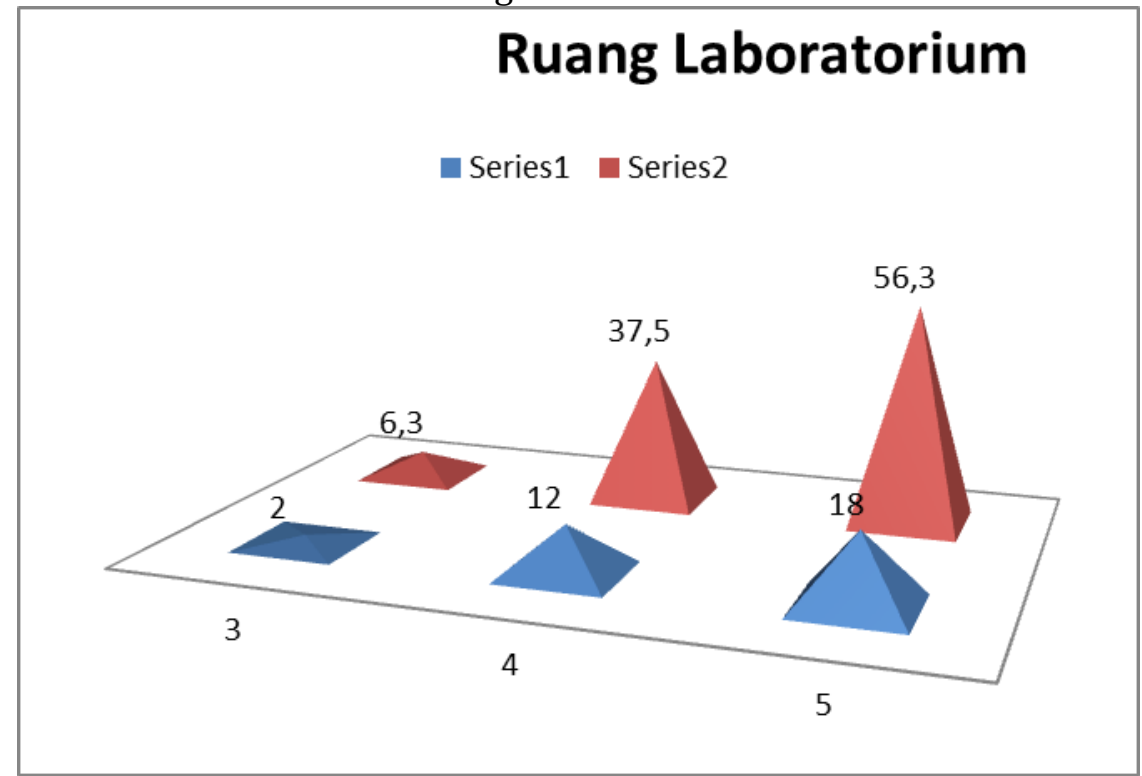

Sumber: Output SPSS, Data Diolah Tahun 2018.

Gambar 9

Komputer

\section{Komputer}

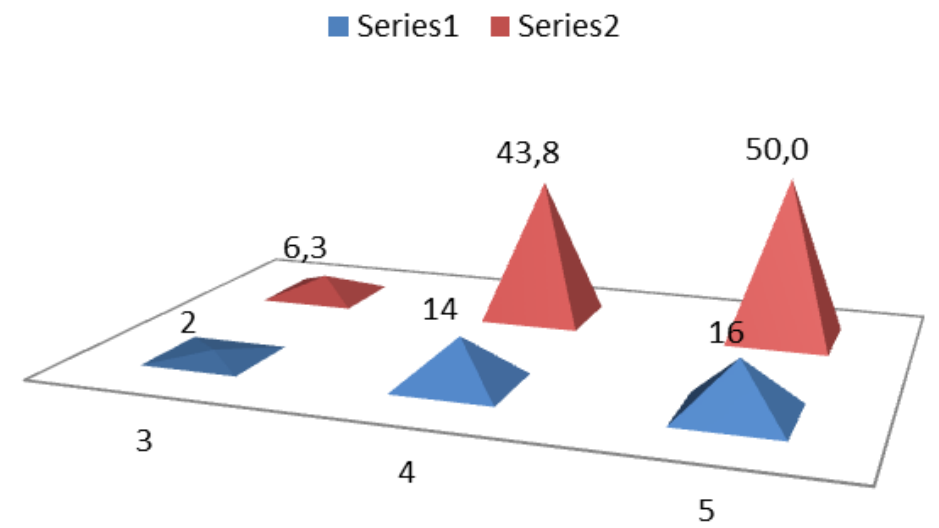

Sumber: Output SPSS, Data Diolah Tahun 2018. 


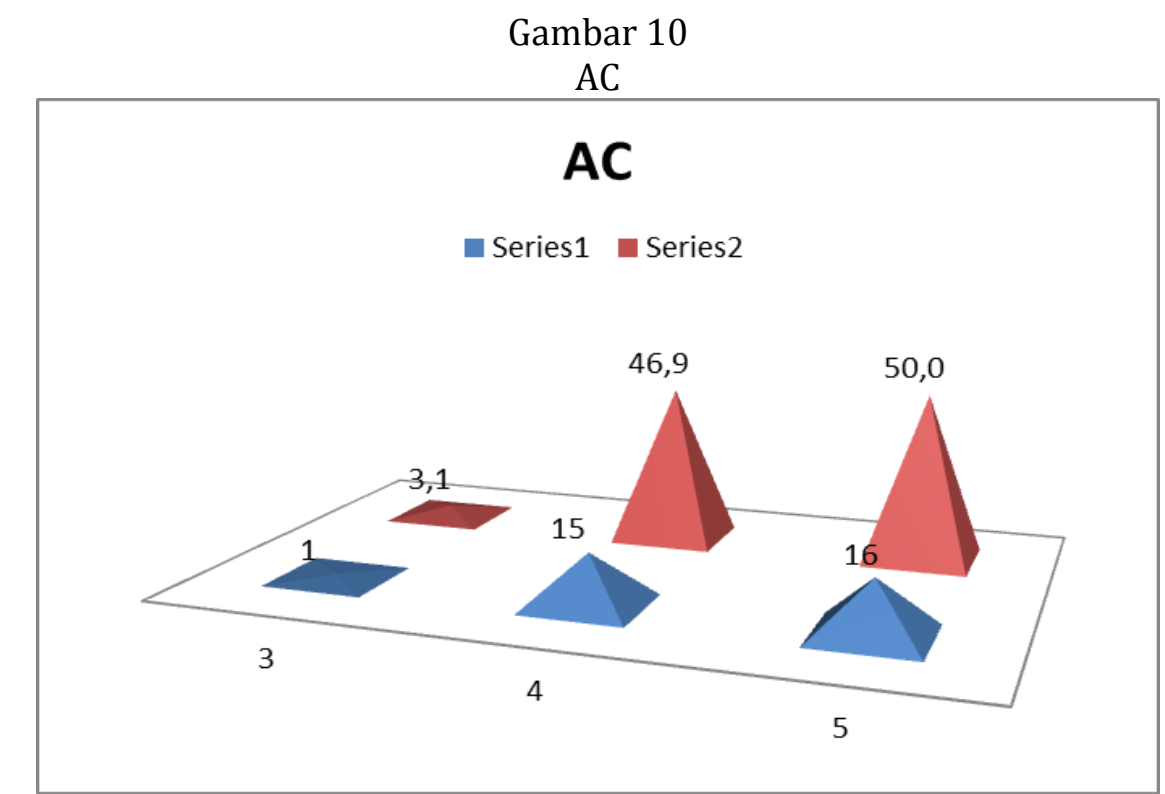

Sumber: Output SPSS, Data Diolah Tahun 2018.

Gambar 11

LCD

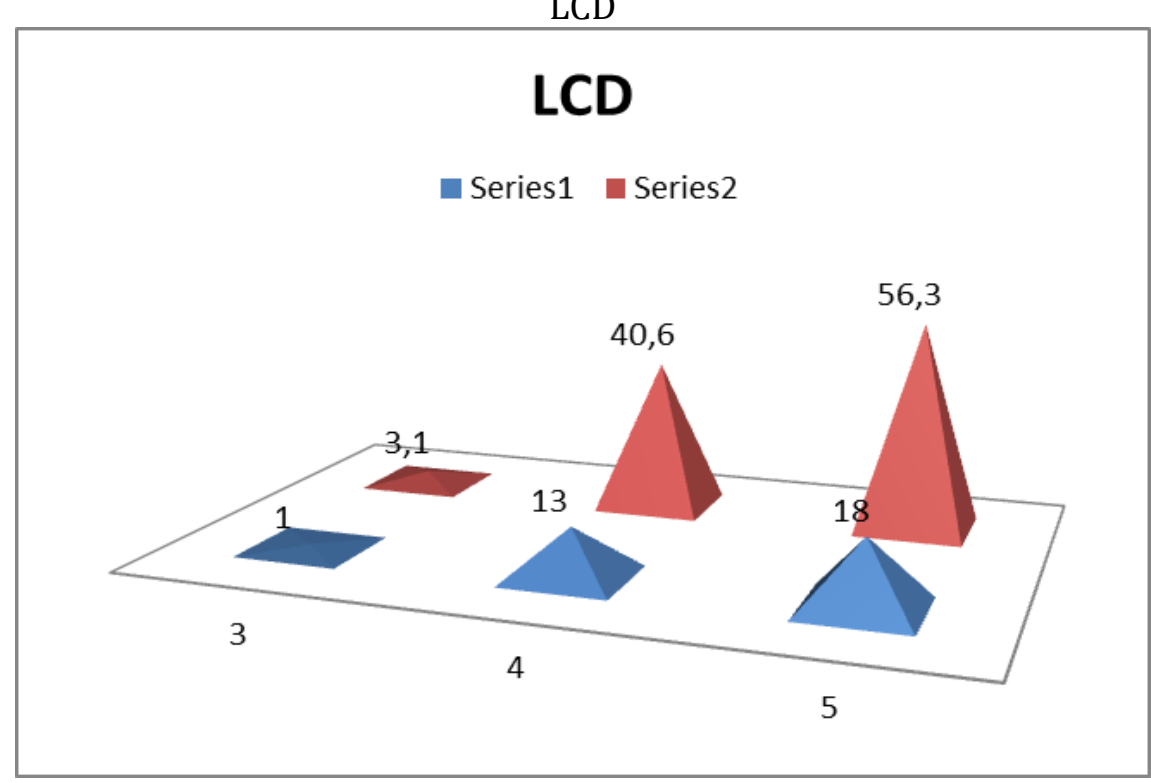

Sumber: Output SPSS, Data Diolah Tahun 2018. 
Gambar 12

Alat-Alat Praktik

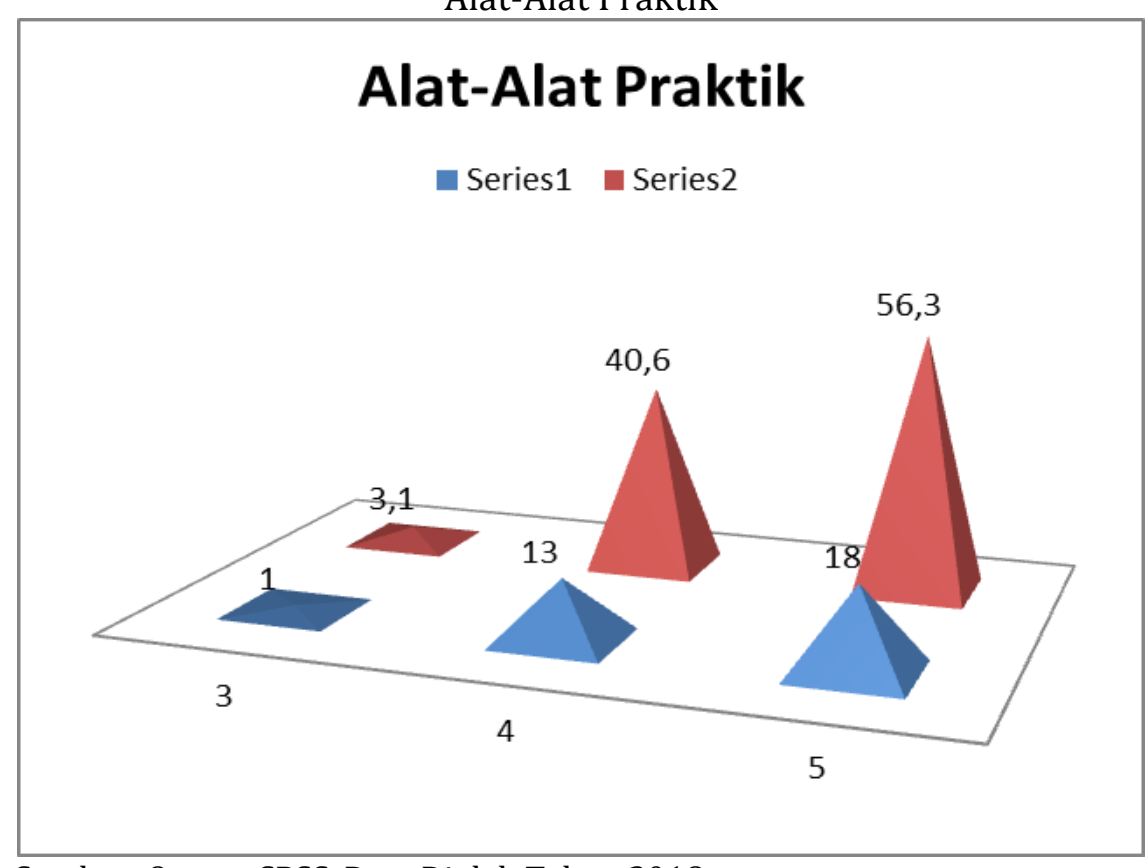

Sumber: Output SPSS, Data Diolah Tahun 2018.

Fasilitas yang ada diantaranya adalah (1), ruangan laboratorium, ruangan ini dapat dilihat dari komentar responden tentang ruangan laboratorium yang menjawab setuju atas fasilitas ini adalah sebanyak $37,5 \%$ dan yang menjawab sangat setuju adalah sebanyak $56,3 \%$ dari unsur dosen sedangkan mahasiswa menjawab setuju adalah sebanyak $16 \%$ dan yang sangat setuju adalah $83 \%$ artinya keberadaan ruangan laboratorium ini sangat penting dan efektif karena merupakan tempat untuk praktek mata kuliah kewirausahaan. (2) komputer, komputer sebagai hardware dan software merupakan perangkat untuk mensupport keberadaan laboratorium hal ini dapat dilihat dari respon responden yang memberikan jawaban setuju sebanyak 43,8\% dan yang menjawab sangat setuju sebanyak $50 \%$ dari unsur dosen dan yang menjawab setuju sebanyak $28 \%$ dan yang sangat setuju adalah sebanyak 71\% dari unsur mahasiswa, (3) Fasilitas AC dengan skor 50\% menunjukkan kesiapan dalam hal ini sangat penting mengingat ditempat kita adalah iklim tropis yang bisa mengganggu kenyamanan dalam beraktifitas di laboratorium entrepreneurship center, (4) Fasilitas LCD dengan skor 56,3\% menunjukkan peralatan yang harus ada di dalam laboratorium entrepreneurship center karena fasilitas ini merupakan alat pendukung yang sangat penting dalam praktek kewirausahaan, (5) alat-alat praktik ini merupakan peralatan pendukung dalam laboratorium entrepreneurship center.

\section{PENUTUP}

Efektivitas laboratorium entreprenneurship center harus di dukung oleh waktu yang tersedia dalam proses belajar mengajar di laboratorium, rata-rata jumlah kelas yang diampu oleh dosen dalam mata kuliah kewirausahaan, dan kemampuan maksimal kelas dalam sehari dalam mengajar kewirausahaan dan kebanyakan responden menjawab dua atau tiga kali saja kemampuan maksimal kelas dalam sehari. Selain itu juga harus didukung oleh fasilitas yang tersedia di laboratorium entrepreneurship center seperti ruangan yang memadai, komputer sebagai perangkat lunak yang dibutuhkan, AC mengingat di tempat kita ini iklimnya sangat 
panas, LCD sebagai perangkat yang memadai untuk menunjang aktivitas laboratorium serta alat-alat praktik yang lain yang mendukung terciptanya laboratorium entrepreneurship center yang memadai.

\section{DAFTAR PUSTAKA}

Andrias Harefa dan Eben Ezer Siadari, The Ciputra Way, Jakarta: Penerbit PT.Elex Media Komputindo, 2010.

Bambang Banu Siswoyo, Pengembangan Jiwa Kewirausahaan di Kalangan Dosen dan Mahasiswa, Jurnal Ekonomi dan Bisnis/Tahun 14/Nomor2/Juli 2009.

Ciputra, Ciputra Quantum Leap, Jakarta: Penerbit PT. Elex Media Komputindo, 2009.

Cheng Har'Abdurrahman', Cara Kerja Generasi Entrepreneur Dunia, Yogyakarta: Taheyya, 2007.

Daryanto, Menggeluti Dunia Usaha, Yogyakarta: Penerbit GAVA MEDIA, 2012.

Hendro, Dasar-Dasar Kewirausahaan, Jakarta: Penerbit, 2011

Ma'ruf Abdullah, Wirausaha Berbasis Syariah, Yogyakarta: Penerbit ASWAJA Pressindo, 2013.

Murti dan Salamah, Metodologi Penelitian Bisnis, Yogyakarta: Andi, 2005.

Mustakim, Pembelajaran kewirausahaan Melalui Kolaborasi Antara Sekolah Dengan Dunia Usaha(Dunia Industri) Pada Siswa SMKN 3 Kudus Tahun 2013, Jurnal Equilibrium, Volume 2, No.1, Juni 2014.

Nana Herdiana Abdurrahman, Manajemen Bisnis Syariah dan Kewirausahaan, Bandung: CV. Pustaka Setia, 2013.

Riduwan. Dasar-Dasar Statistika. Bandung: Alfabeta, 2009.

Sugiono, Statistika Untuk Penelitian, Bandung: Alpha Beta, 2000.

Tasmara, KH.Toto, Membudayakan Etos Kerja Islami, Jakarta: Penerbit GEMA INSANI Press, 2002.

Wiedy Murtini, Sri Sumaryati, Leny Noviani, Pengembangan Laboratorium Kewirausahaan Terpadu Prodi Pendidikan Ekonomi, (Cakrawal Pendidikan, Juni 2014, Th.XXXIII.No.2). 